
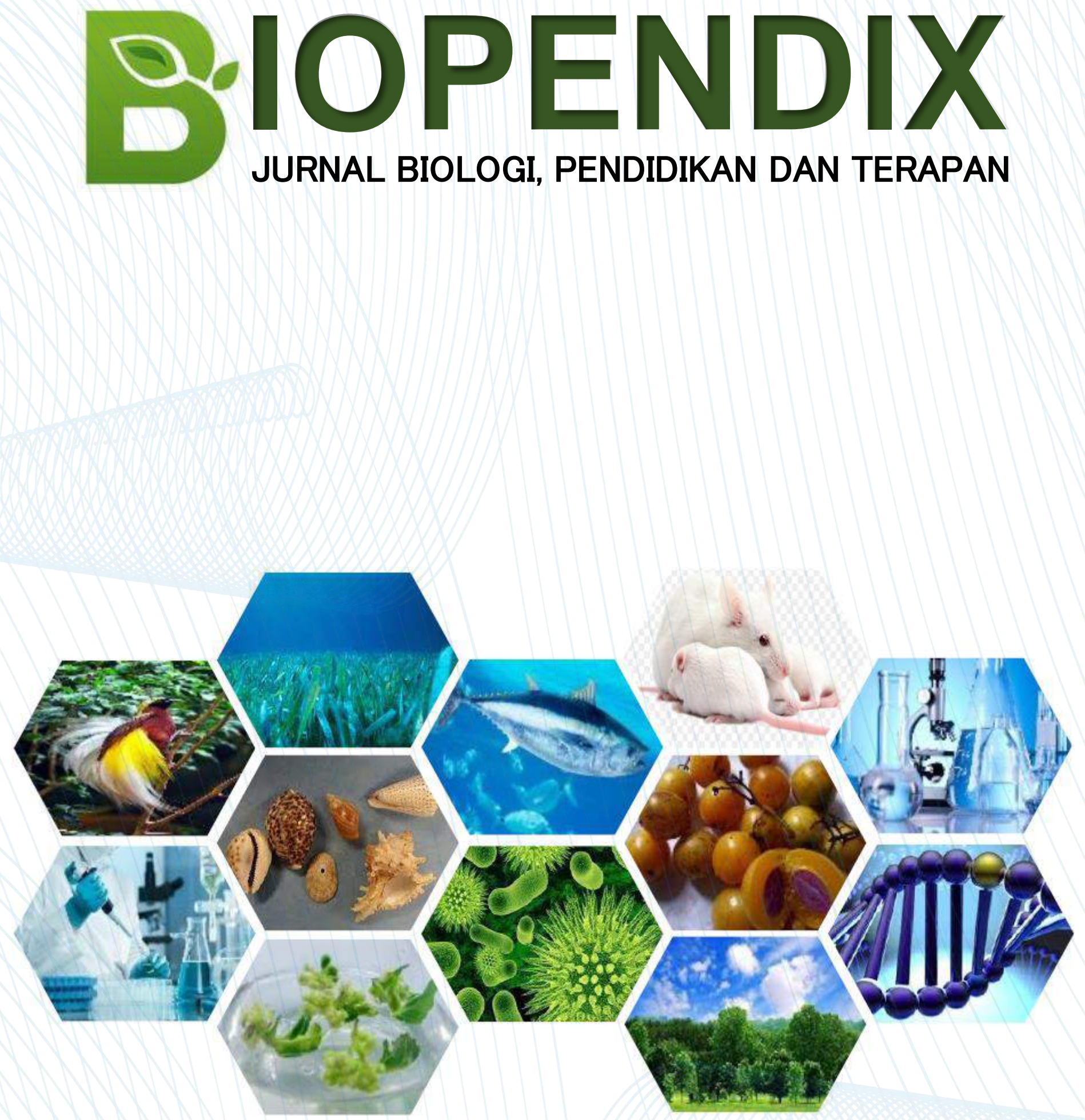

PUBLISHER BY:

BIOLOGY EDUCATION, UNPATTI AMBON - MALUKU 


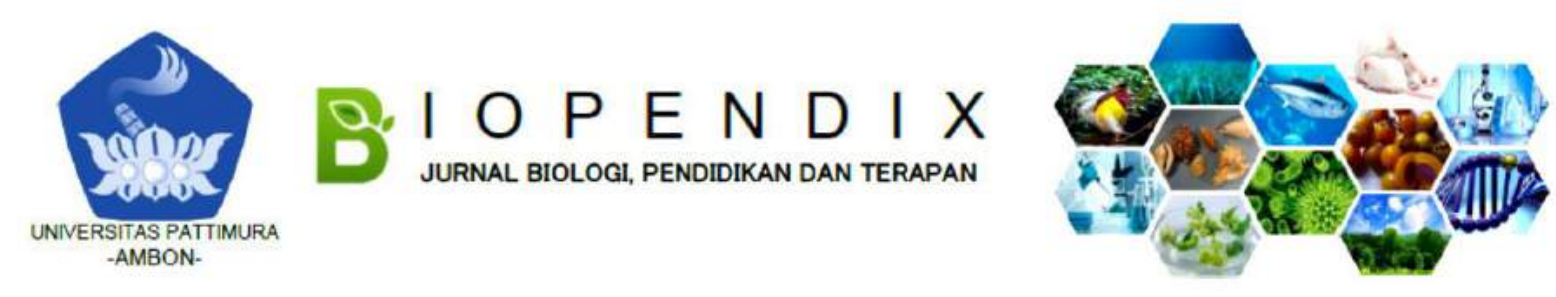

\title{
PERPADUAN MODEL PEMBELAJARAN STUDENT FACILITATOR AND EXPLAINING DENGAN COURES REVIEW HORAY DALAM MENINGKATKAN HASIL BELAJAR SISWA SMP NEGERI 7 AMBON
}

\author{
Reni S. YangLera1, J.F. Rehena², P.M.J Tuapattinaya² \\ ${ }^{1}$ Alumni Program Studi Pendidikan Biologi; ${ }^{2}$ Program Studi Pendidkan Biologi \\ Corresponding author: P.M.J Tuapattinaya; \\ e-mail: pmjtuapattinaya.unpatti@gmail.com
}

\begin{abstract}
Background: In an effort to improve Biology learning outcomes at school, teachers need to apply learning models that enable students to achieve these needs. One learning model used by researchers is the Student Facilitator and Explaining learning model combined with the Coures Review Horay model. Student Facilitator and Explaining makes students as facilitators, namely providing opportunities for students to explain or convey ideas to other students. While Coures Review Horay asks students to write answers to questions on a given card that has a number.

Method: This research includes descriptive research and analysis used to determine the effectiveness of the application of the model using manual analysis. The data source in this study was students of class VIII-1 SMP Negeri 7 Ambon with a total of 30 students.

Results: The application of the Student Facilitator And Explaining learning model combined with the Course Review Horay model can improve the learning outcomes of the Human Digestive System material in Grade VIII students of SMP Negeri 7 Ambon. This result is seen in the average value obtained at the final value of 79.70 .

Conclusion: There are differences in learning outcomes before and after the implementation of the Student Facilitator and Explaining learning model combined with the Coures Review Horay model in the Human Digestive System material.
\end{abstract}

Keywords: Student Facilitator and Explaining and Coures Review Horay, Learning Outcomes Abstrak

Latar Belakang: Dalam usaha meningkatkan hasil belajar Biologi disekolah, guru perlu menerapkan model pembelajaran yang memungkinkan siswa untuk mencapai kebutuhan tersebut. Salah satu model pembelajaran yang digunakan peneliti adalah model pembelajaran Student Facilitator and Explaining dipadukan model Coures Review Horay. Student Facilitator and Explaining menjadikan siswa sebagai facilitator yaitu memberikan kesempatan kepada siswa untuk menjelaskan atau menyampaikan ide kepada siswa-siswa lain. Sedangkan Coures Review Horay meminta siswa untuk menuliskan jawaban soal pada kartu yang diberikan yang telah dilengkapi nomor.

Metode: Penelitian ini termasuk penelitian Deskriptif dan Analisis yang digunakan untuk mengetahui efektifitas dari penerapan model menggunakan analisis secara manual. Sumber data dalam penelitian ini adalah siswa kelas VIII-1 SMP Negeri 7 Ambon dengan jumlah keseluruhan 30 siswa.

Hasil: Penerapan model pembelajaran Student Facilitator And Explaining dipadukan model Course Review Horay dapat meningkatkan hasil belajar materi Sistem Pencernaan Manusia pada siswa kelas VIII SMP Negeri 7 Ambon. Hasil ini terlihat pada nilai rata-rata yang diperoleh pada nilai akhir yaitu 79,70 .

Kesimpulan: Terdapat perbedaan hasil belajar sebelum dan sesudah diterapkannya model pembelajaran Student Facilitator and Explaining dipadukan model Coures Review Horay pada materi Sistem Pencernaan Manusia.

Kata kunci: Student Facilitator and Explaining dan Coures Review Horay, Hasil Belajar 


\section{PENDAHULUAN}

Pendidikan merupakan suatu usaha sadar yang sengaja dirancang untuk mencapai tujuan yang telah ditetapkan. Pendidikan bertujuan untuk meningkatkan kualitas sumber daya manusia. Pendidikan sangat penting bagi kelangsungan kehidupan suatu bangsa, sebab kualitas kehidupan suatu bangsa sangat erat dengan tingkat pendidikan. Menurut Sanjaya (2013), salah satu masalah yang di hadapi dunia pendidikan kita adalah masalah lemahnya proses pendidikan. Dalam usaha meningkatkan mutu pendidikan tersebut banyak faktor atau strategi yang bisa digunakan untuk mengimplementasikannya. Salah satu faktor yang mempengaruhi mutu pendidikan adalah proses pembelajaran. Untuk meningkatkan kualitas pembelajaran bisa dilakukan dari berbagai aspek diantaranya adalah proses belajar mengajar. Hal yang lebih penting dalam belajar adalah bukan hanya mengingat informasi-informasi penting dari pelajaran, tetapi bagaimana agar bisa menampilkan unjuk kerja dalam menerapkan informasi tersebut untuk memecahkan masalah-masalah baru (Uno \& Nurdin, 2011). Salah satunya yang dapat dilihat dari proses belajar adalah hasil belajar itu sendiri. Hasil belajar diukur untuk mengetahui ketercapaian tujuan pendidikan melalui proses belajar mengajar karena hasil belajar termasuk komponen pendidikan yang harus disesuaikan dengan tujuan pendidikan (Purwanto, 2011). Untuk mencapai tujuan pendidikan manusia tidak dapat lepas dari proses belajar itu sendiri sampai kapanpun dan dimanapun manusia berada dan belajar juga menjadi kebutuhan yang terus meningkat sesuai dengan perkembangan Ilmu Pengetahuan.

Pada dasarnya pelajaran IImu Pengetahuan Alam khususnya Biologi merupakan bagian dari sains yang mengkaji tentang kehidupan, lingkungan sekitar, interaksi antara kehidupan dengan lingkungan sekitar dan fenomena yang berkaitan dengannya. Sebagai salah satu ilmu sains yang saat ini berkembang amat pesat baik materi maupun kegunaannya, perkembangan biologi itu sendiri, masih saja terdapat kekeliruan dalam mempelajari biologi yakni sering dianggap sebagai ilmu yang sukar, sulit atau membosankan untuk dipelajari. Sehingga anggapan demikian akan mengurangi minat siswa terhadap proses pembelajaran biologi dan mengakibatkan rendahnya prestasi belajar siswa. Prinsip tersebut menjadi dasar untuk memilih model pembelajaran yang tepat. Suatu proses pembelajaran akan mencapai hasil yang diharapkan apabila direncanakan dengan baik oleh guru (Slameto, 2003).

Model pembelajaran yang digunakan haruslah bersifat interaktif, inspiratif, menyenangkan, menumbuhkan kreatifitas dan kemandirian siswa sesuai dengan kemampuannya. Penggunaan model pembelajaran yang tepat akan meningkatkan hasil belajar yang dapat dilihat dari proses pembelajarannya. Model pembelajaran yang dapat mengaktifkan dan meningkatkan hasil belajar siswa di antaranya model Student Facilitator and Explaining (SFE) dan model Course Review Horay (CRH). Model Student Facilitator and Explaining (SFE) merupakan salah satu model pembelajaran inovatif (Widodo, 2009). Peserta didik diberi kesempatan untuk menjelaskan pendapat kepada teman-temannya. Dengan proses pembelajaran seperti ini siswa dapat meningkatkan keaktifan, minat, motivasi dan kreativitas siswa dalam berpikir sehingga proses belajar mengajar akan lebih menarik dan menyenangkan. Menurut Hamdani (2013), model Course Review Horay merupakan model pembelajaran yang dapat menciptakan suasana pembelajaran menjadi meriah dan menyenangkan karena setiap siswa yang dapat menjawab pertanyaan dengan benar diwajibkan bersorak hore atau menyanyikan yel-yel. Model ini berusaha untuk menguji pemahaman siswa dalam menjawab soal, dimana jawaban soal tersebut ditulis pada kartu yang telah dilengkapi nomor. Student Facilitator and Explaining diterapkan untuk memotivasi siswa berani mengemukakan pendapatnya, dan saling memberikan pendapat. Dalam model Student Facilitator and Explaining siswa dapat menerangkan melalui bagan atau gambar, sedangkan Coures Review Horay ini berusaha menguji pemahaman siswa dalam menjawab soal. Siswa atau kelompok yang memberi jawaban benar harus langsung berteriak 'hore'. Model pembelajaran ini dapat mendorong siswa untuk terjun kedalamnya, 
metode yang tidak monoton karena diikuti dengan hiburan sehingga suasana tidak menengangkan (Hamdani, 2013).

\section{METODE}

Tipe penelitian yang digunakan adalah tipe deskriptif untuk mengungkapkan hasil belajar siswa dengan penggunaan model pembelajaran Student Facilitator and Explaining dipadu model Coures Review Horay materi Sistem Pencernaan Manusia pada siswa kelas VIII di SMP Negeri 7 Ambon. Tempat penelitian ini dilaksanakan di sekolah SMP Negeri 7 Ambon kelas VIII1, Penelitian ini dilaksanakan pada Tanggal 27 dan 30 Maret 2019. Subjek dalam penelitian ini adalah 1 kelas yaitu siswa kelas VIII-1 dengan jumlah sebanyak 30 siswa. Variabel bebas dalam penelitian ini adalah penerapan model pembelajaran Student Facilitator and Explaining dipadukan model Coures Review Horay. Variabel terikat berupa hasil belajar siswa.

Setelah data terkumpul maka kemudian diolah dengan menggunakan analisa deskripsif untuk memperoleh Nilai Akhir (NA). Arikunto, 2001 menyatakan bahwa guru mempunyai pendapat tersendiri tentang cara penentuan nilai akhir (hasil belajar), yang dipengaruhi pandanganpandangan tentang bagian-bagian kegiatan. Maka nilai akhir (NA) yang menggambarkan tingkat pengguasaan individu terhadap indikator kompetensi materi sistem pencernaan pada manusia dari segi hasil maupun proses di peroleh dengan rumus:

$$
N A=\frac{6 P+4 F}{10}
$$

\section{HASIL DAN PEMBAHASAN Nilai akhir}

Nilai akhir merupakan hasil belajar siswa yang dapat diketahui dari presentase tingkat kemampuan atau penguasaan siswa pada nilai proses dari aspek kognitif, afektif dan psikomotor dan presentase kemampuan atau penguasaan siswa pada hasil tes (Tes awal dan Tes akhir). Tingkat kemampuan atau penguasaan setiap siswa berbeda-beda, ini dapat terlihat dari hasil nilai akhir. Data Nilai Akhir (NA) dapat dilihat pada tabel di bawah ini:

Tabel 1. Klasifikasi Presentase Nilai Akhir

\begin{tabular}{cccc}
\hline Interval & Frekuensi & Presentase (\%) & Keterangan \\
\hline $90-100$ & - & - & Sangat baik \\
$80-89$ & 13 & 50 & Baik \\
$69-79$ & 13 & 50 & Cukup \\
$<69$ & - & - & Gagal \\
\hline Jumlah & 26 & $100 \%$ & - \\
\hline
\end{tabular}

Berdasarkan tabel nilai akhir, hasilnya terdapat 13 siswa dengan presentase $50 \%$ memperoleh nilai pada interval (80-89) dengan keterangan baik, 13 siswa dengan presentase $50 \%$ memperoleh nilai pada interval (69-79) dengan keterangan cukup.

Berdasarkan data yang diperoleh setelah proses belajar mengajar dengan menerapkan model pembelajaran Student Facilitator And Explaining dipadukan model Coures Review Horay terlihat bahwa, pada siswa kelas VIII-1 telah mencapai nilai Kriteria Ketuntasan Minimal (KKM) 69 yang diperoleh dari pengerjaan soal-soal tes akhir. Hasil tes akhir siswa menunjukan bahwa presentase pencapaian tes akhir terhadap 26 siswa terlihat bahwa 4 siswa memperoleh presentase $15,38 \%$ mampu menguasai indikator sangat baik, hal ini disebabkan karena siswa-siswi tersebut mampu menjawab serta menyelesaikan soal-soal yang diberikan dan 12 siswa dengan presentase 46,15\% mampu menguasai indikator pembelajaran dengan baik, dan 10 siswa dengan presentase $38,46 \%$ mampu menguasai indikator pembelajaran dengan keterangan cukup. Hal ini menunjukan bahwa siswa sudah mampu menyelesaikan soal-soal yang diberikan namun belum sempurna.

Hasil pada nilai akhir belajar siswa kelas VIII-1 SMP Negeri 7 Ambon mengalami peningkatan pada materi Sistem Pencernaan Manusia yang diperoleh dari 
proses belajar mengajar dengan menggunakan penerapan model Student Facilitator and Explaining dipadukan model Coures Review Horay. Hal ini sesuai dengan hasil penelitian yang dilakukan oleh Andari (2013) yang menyatakan bahwa pelaksanaan pembelajaran dengan model Student Facilitator and Explaining dapat meningkatkan hasil belajar karena siswa terlibat secara langsung dalam proses pembelajaran, model tersebut juga melatih siswa untuk menyampaikan pendapatnya dan melatih keberanian berbicara didepan kelas. Hasil penelitian juga dilakukan oleh Pratiwi (2011) yang menyimpulkan bahwa penerapan model Coures Review Horay dapat meningkatkan aktivitas dan hasil belajar siswa dalam pembelajaran IPA. Menurut Isjoni 2012, model pembelajaran Student Facilitator And Explaining merupakan model pembelajaran kooperatif yang melibatkan keaktifan siswa, menjadikan siswa sebagai fasilitator, diajak berpikir secara kreatif dan siswa mampu menyerap ilmu dengan baik.

Pencapaian kompetensi siswa meliputi aspek kognitif siswa dalam mengerjakan LKS yang diberikan pada masing-masing siswa. Aspek afektif dan aspek psikomotor dalam lembaran penilaian serta hasil tes formatif (Tes akhir) dapat dilihat pada pengerjaan soal-soal tes akhir dan nilai akhir (NA) maka pencapaian nilai akhir terlihat bahwa 26 siswa berhasil memperoleh nilai di atas KKM 69.

\section{SIMPULAN}

Berdasarkan hasil penelitian yang telah dipaparkan, maka dapat disimpulkan bahwa penggunaan model pembelajaran Student Facilitator and Explaining dipadukan model Coures Review Horay dapat meningkatkan hasil belajar siswa. Peningkatan hasil belajar pada materi Sistem Pencernaan Manusia mendapatkan peningkatan yang cukup baik. Hal ini sesuai dengan analisis data yang diperoleh dari nilai akhir yaitu 79,7 .

\section{DAFTAR PUSTAKA}

Andari, D. W. (2013) Penerapan Model Pembelajaran Student Facilitator and Explaining untuk Meningkatkan Hasil Belajar Fisika kelas VIII SMP Nurul Islam. Skripsi tidak diterbitkan. Semarang: UNNES.

Arikunto. (2001) Prosedur Penelitian Suatu Pendekatan Pendidikan Praktik. Jakarta: Rineka Cipta.

Hamdani, 2013. Model Pembelajaran Coures Review Horay. Bandung: CV Pustaka Setia.

Isjoni. 2012. Cooperative Learning Efektifitas Pembelajaran Kelompok. Bandung:Alfabeta.

Pratiwi, L. 2011. Penerapan Model Coures Review Horay (CRH) Untuk Meningkatkan Pembelajaran IPA Siswa Kelas IV SDN Merjosari Malang.Universitas Negeri Malang.

Purwanto. 2011. Evaluasi Hasil Belajar. Yogyakarta: Pustaka Belajar.

Sanjaya. 2013. Penelitian Pendidikan, Jenis, Metode dan Prosedur. Jakarta: Kencana Prenada Media Group

Slameto. 2003. Belajar dan Faktor-faktor yang Mempengaruhinya. Bina Aksara. Jakarta.

Uno, H. B. \& Mohamad, N. 2011. Model Pembelajaran Menciptakan Proses Belajar Mengajar yang Kreatif dan Efektif. Jakarta: Bumi Aksara.

Widodo, R. 2009. Model Pembelajaran Course Review Horay. http://wyw1d.wordpress.com/.(13 Oktober 2018). 